\title{
Intralesional Bleomycin Sclerotherapy in Children with Lymphangiomas: A Review Article
}

\author{
Volkan Sarper Erikci* \\ Sağlik Bilimleri University, Department of Pediatric Surgery, Tepecik Training Hospital, Turkey
}

*Corresponding author: Volkan Sarper Erikci, Associate Professor of Pediatric

Surgery, Tepecik Training Hospital, Turkey.

Received Date: November 25, 2020

Published Date: December 14, 2020

\begin{abstract}
Lymphangioma is a benign tumor of lymphatic vessels. Swelling and cosmetic deformity are the most common symptoms. As a sclerosing agent, bleomycin has been used in the management of patients with these lesions with successful outcomes. In this review the topic is discussed, and a brief literature review is given. Intralesional injection of bleomycin in children with lymphangioma is an effective method of treatment and it usually achieves excellent results in most of the patients with minimal side effects.
\end{abstract}

Keywords: Lymphangioma; Bleomycin; Intralesional sclerotherapy

\section{Introduction}

Lymphangiomas are congenital hamartomatous malformations of lymphatic system and consist of cystic spaces of varying size. Head and neck are the most frequently affected sites accounting for $75 \%$ of all cases $[1,2]$. The reported incidence of lymphangioma is 1.5 to 2.8 per 1000 across both gender and all races [3]. It usually manifests at birth in up to $65 \%$ of cases and presents by 2 nd year of life in $80-90 \%$ of cases $[1,4,5]$. Traditional management of lymphangioma is surgical excision and it is aimed to remove the involved tissue without sacrificing vital structures. This goal cannot usually be obtained with surgical intervention alone. Besides surgical treatment involves complications including wound infection, hemorrhage, unsightly scar, postoperative fluid accumulations, various nerve palsies and lymphorrhea [6]. Due to above mentioned situations, intralesional sclerotherapy of lymphangiomas has been popularized recently. In this review article, intralesional sclerotherapy of lymphangiomas with special relevance to bleomycin usage is reviewed and discussed under the light of relevant literature.

\section{Discussion}

Management of lymphatic malformations using sclerotherapy injections of different agents into the lesions became a treatment option when it was noted that lymphangiomas spontaneously involuted when they became infected. The first lymphangioma case treated by intralesional sclerotherapy was reported in 1933 using sodium morrhuate. Since then various sclerosing agents including OK 432, iodine, ethanolamine oleate boiling water, quinine, pingyangmycin, urethane, pure alcohol, sotradecaol, doxycycline, ethanol, sodium tetradecyl sulfate, acetic acid, hypertonic saline, ethibloc and bleomycin [3,7-10].

The first isolation of bleomycin was in 1966 by Umezawa as an anti-tumour, anti-viral and anti-bacterial agent [11]. The basic action of bleomycin is inhibition of DNA synthesis biochemically. Although the mechanism is not fully understood, it has been suggested that it causes fibrosis in the lesion in a non-inflammatory manner with a sclerosing effect on vascular endothelium $[11,12]$. Most of the studies reveal that the effectiveness of bleomycin is the 
most in macrcystic lesions $[7,13]$. But it has also been shown that after 6th dose of intralesional injection all variants of lymphangioma responded well [14].

The typical complications of intralesional bleomycin treatment are erythema, oedema, pigmentation of the skin, transient hair loss and fever $[15,16]$. It has been reported that these nonserious complications occurred in $25-63 \%$ of patients treated with intralesional bleomycin injection [3,16-22]. Induration and oedema may be life threatening if the lesions are close proximity to the upper airways especially in patients younger than 3 months of age so it has been suggested that children younger than 3 months of age should be admitted to hospital for 48 hours in order to avoid upper airway obstruction [14]. Mortality after injection of bleomycin is not commonly observed but it was reported in 3 cases out of 70 patients in a previous study [23]. Systemic absorption of bleomycin after intraparenchymal injection is another concern in intralesional bleomycin treatment of lymphangiomas and it has been suggested that $0 \mathrm{~K}-432$ should be the first injection option if systemic absorption of the agent used is a matter [3]. In order to reduce discomfort for the patient postoperatively, it has been suggested that solution of bleomycin should be prepared by addition of lignocaine $2 \%$ along with normal saline with a ratio of $1: 1[24]$.

The primary consideration of bleomycin therapy is the risk of pulmonary toxicity. The risk is dose related and at total doses of below $150 \mathrm{mg}$ or $450 \mathrm{U}$ or a single dose exceeding $30 \mathrm{mg} / \mathrm{m} 2$ of body surface area given intravenously to oncology patients life threatening toxicity is rare $[3,25,26]$. Although a definitive link to the bleomycin therapy was not shown, it is reported that the two children treated with intralesional bleomycin sclerotherapy died postoperatively from pulmonary complications [4].

There is no uniformity about the dose of bleomycin in the reported series. Doses of 0.3-1.8 IU/kg has been suggested [4,16,19,27-29]. These injections are given at 2-week-2 months intervals and cumulative amount of injected bleomycin is up to 15 $\mathrm{IU} / \mathrm{kg}$ or $50 \mathrm{mg}$ in total or $5 \mathrm{mg} / \mathrm{kg}[5,7,28]$.

\section{Conclusion}

In conclusion, lymphangioma is a rare but an important clinical entity. Bleomycin sclerotherapy is an effective treatment modality for the management of lymphangiomas and it should be first line modality before surgical treatment. Ease of treatment, early intervention and good response makes it favorable treatment choice. Accurate management of these children with bleomycin sclerotherapy is recommended. The health providers dealing with such kinds of patients should keep this treatment option in mind and a prompt pediatric surgical consultation is recommended and the patient should be treated accordingly.

\section{Acknowledgement}

None.

\section{Conflict of Interest}

No conflict of interest.

\section{References}

1. Ravitch MM, Rush BF (1986) Cystic hygroma. In: Welch KJ, Randolph MM, Ravitch MM, et al. (eds), Pediatrc Surgery. Yearbook Medical, USA, pp. 533-539.

2. Emery PJ, Bailey CM, Evans JN (1984) Cystic hygroma of the head and neck: a review of 37 cases. J Laryngol Otol 98(6): 613-619.

3. Rozman Z, Thambidorai CR, Zaleha AM, Zakaria Z, Zulfiqar ZA (2011) Biomed Imaging Interv J 7(3): 1-8.

4. Acevedo JL, Shah RK, Brietzke SE (2008) Nonsurgical therapies for lymphangiomas: a systematic review. Otolaryngol Head Neck Surg 138(4): 418-424.

5. Sanlialp I, Karnak I, Tanyel FC, Șenocak ME, Büyükpamukçu N (2003) Sclerotherapy for lymphangioma in children. Int J Pediatr Otolaryngol 67(7): 795-800

6. Bilici S, Avci V, Öztaş T, Asena M, Çelik K (2019) The treatment of lymphangiomas with bleomycin in childhood: a retrospective observational study. Haydarpasa Numune Med J 59(4): 315-319.

7. Erikci V, Hoşgör M, Yildiz M, Örnek Y, Aksoy N, et al. (2013) Intralesional bleomycin sclerotherapy in childhood lymphangioma. Turk J Pediatr 55(4): 396-400.

8. Kulungowski A, Fishman S (2012) Vascular anomalies. In: Coran AG, Adzick NS, Krummel TM, Laberge JM, Shamberger RC, et al. (eds), Pediatr Surg $7^{\text {th }}$ (edn), Saunders Elsevier, USA, pp. 1621-1624.

9. Bagrodia N, Defnet AM, Kandel JJ (2015) Management of lymphatic malformations in children. Curr Opin Pediatr 2793): 356-363.

10. Cheng J (2015) Doxycycline sclerotherapy in children with head and neck lymphatic malformations. J Pediatr Surg 50(12): 2143-2146.

11. Umezawa H (1978) Recent study on biochemistry and action of bleomycin. In: Carter SK, Crook ST, Umezawa H (eds), Bleomycin: Current status and new developments, Academic Press, USA, pp.15-20.

12. Perkins JA, Manning SC, Tempero RM, Cunningham MJ, Edmonds JL, et al. (2010) Lymphatic malformations: review of current treatment. Otolaryngol Head Neck Surg 142(6): 795-803.

13. Steupp RT, Scotti FM, Melo G, Munhoz EA, Modolo F (2019) Effects of sclerosing agents on head and neck hemangiomas: a systematic review. J Clin Exp Dent 11(11): e1033-e1044.

14. Tiwari P, Pandey V, Bera RN, Sharma SP, Chauhan N (2019) Bleomycin sclerotherapy in lymphangiomas of the head and neck region: a prospective study. Int J Oral Maxillofac Surg

15. MacIntosh PW, Yoon MK, Fay A (2014) Complications of intralesional blemycin in the treatment of orbital lymphatic malformations. Semin Ophthalmol 29(5-6): 450-455.

16. Orford J, Barker A, Thonell S, King P, Murphy J (1995) Bleomycin therapy for cystic hygroma. J Pediatr Surg 30(9): 1282-1287.

17. Kumar V, Kumar P, Pandey A, Gupta DK, Shukla RC, et al. (2012) Intralesional bleomycin in lymphangioma: an effective and safe nonoperative modality of treatment. J Cutan Aesthet Surg 5: 133-136.

18. Pradyumna P (2017) Ultrasound guided intralesional bleomycin therapy for cystic lymphagioma in childhood. Int J Contemp Pediatric 4: 14961500

19. Okada A, Kubota A, Fukuzawa M, Imura K, Kamata S (1992) Injection of bleomycin as a primary therapy of cystic lymphangioma. J Pediatr Surg 27(4): 440-443.

20.Zulfiqar MA, Zaleha AM, Zakaria Z (1999) The treatment of neck lymphangioma with intralesional injection of bleomycin. Med J Malaysia 54(4): 478-481. 
21. Tanigawa N, Shimomatsuya T, Takahashi K, Inomata Y, Tanaka K, et al. (1987) Treatment of cystic hygroma and lymphangioma with the use of bleomycin fat emulsion. Cancer 60(4): 741-749.

22. Mahajan JK, Bharathi V, Chowdhary SK, Samujh R, Menon P, et al. (2004) Bleomycin as intralesional sclerosant for cystic hygromas. J Indian Assoc Pediatr Surg 9(1): 3-7.

23. Niramis R, Watanatittan S, Rattanasuwan T (2010) The treatment of cystic hygroma by intralesional bleomycin injection: experience in 70 patients. Eur J Pediatr Surg 20(3): 178-182.

24. Nuruddin M, Roy SR, Mudhar HS (2019) Results of intralesional bleomycin sclerotherapy for treatment of orbital lymphangiomas at a tertiary eye care centre in Bangladesh. Ocul Oncol Pathol 5(6): 412-417.

25. Balis FM, Holcenberg JS, Blaney SM (2001) Genreal principles of chemotherapy. In: Pizzo PA and Poplack DG (eds), Principles and practice of pediatric oncology $4^{\text {th }}(\mathrm{edn})$, Lippincott Williams $\&$ Wilkins, pp. 274-275.
26. Dorr RT, Von Hoff DD (1994) Drug monographs, bleomycin sulfate. In: Dorr RT, von Hoff (eds), Cancer Chemotherapy Handbook $2^{\text {nd }}(\mathrm{edn}), \mathrm{pp}$. 227-235.

27. Jiang JP (1989) Local injection of bleomycin in lymphangioma in children: analysis of 100 cases. Chung Hua Wai Ko Tsa Chih 27: 741-744.

28. Stringel G (2000) Hemangiomas and lymphangiomas. In: Aschraft KW (edr), Pediatric Surgery $3^{\text {rd }}$ (edn), WB Saunders Company, pp. 965-986.

29. Parashar G, Shankar G, Sahadev R, Santhanakrishnan R (2020) Intralesional sclerotherapy with bleomycin in lymphatic malformation of tongue: an institutional experience and outcomes. J Indian Assoc Pediatr Surg 25(2): 80-84. 